Скареднов Д. Ю., аспірант*

Полтавська державна аграрна академія

\title{
ЗАБІЙНІ ТА М'ЯСНІ ЯКОСТІ СВИНЕЙ НА ВІДГОДІВЛІ ЗА ВИКОРИСТАННЯ В РАЦІОНАХ КОНЦЕТРАТУ СУХОГО БІЛКОВОГО СОЄВОГО КОРМОВОГО
}

\section{Рецензент - кандидат сільськогосподарських наук Н. Д. Голуб}

\begin{abstract}
Наведені результати дослідження забійних $i$ м'ясних якостей свиней, відгодованих на раціонах із додаванням білкових соєвих кормів різних технологій виробництва: експандування під тиском (концентрат сухий білковий кормовий соєвий), віджим під пресом (макуха соєва), екструзія (екструдат соєвий). За контролем використана макуха соняшникова. Встановлено суттєву позитивну дію ефективності білкових соєвих кормів на інтенсивність росту, конверсію корму, забійні та м'ясні якості свиней, морфологічний склад туш. Найкращими за забійним виходом туші були аналоги свиней, відгодовані на макусі соєвій та кониентраті сухому білковому соєвому кормовому $(+2,47 \%$ та 1,53\% відповідно до контролю). В ичілому м'ясо-сальна продукиія піддослідних тварин за основними показниками якості відноситься до нормальної категорї свинини.
\end{abstract}

Ключові слова: соя, експандування, віджим, екструзія, забій, м'ясність, якість, ипик, категорія.

Постановка проблеми. Свинарство - одна 3 основних галузей тваринництва, яка може забезпечити значну частину біологічних потреб людини в м'ясопродуктах. Водночас із проблемою кількості м'яса та м'ясопродуктів виникає проблема їх якості, передусім якість туш. На разі йдеться про отримання пісної свинини, яка повинна вироблятися на раціонах із використанням білкових жировмісних екологічно чистих кормів, що $\epsilon$ актуальним на даному етапі в розвитку свинарства. У цьому плані результативно використовуються білкові корми із сої, виготовлені за різними технологіями. Тому дане дослідження має актуальний характер.

Аналіз основних досліджень і публікацій, у яких започатковано розв'язання проблеми. Узагальнюючи багаторічні дослідження вчених, доведено, що забійні та м'ясні якості свиней залежать як від породних особливостей тварин $[3,2]$, так і від їх годівлі [6-9].

У вирішенні проблеми отримання якісної пісної свинини заслуговує на увагу питання збалансованості раціонів свиней за рахунок використання кормів із сої, поскільки вони найбільш економне джерело високоякісного білку й енергії $[1,4,5,10]$. Дослідженнями Б. Д. Шаталіна (1975), А. Е. Чикова (1979), І. С. Трончука, А. А. Поліщука (1989), С. О. Семенова (1997) встановлено, що використання сої різних технологій виробництва (екструзія, температурна обробка агрегатами, мікронізація, відходи маслоекстракційного виробництва) сприяе підвищенню ефективності вирощування та м'ясної відгодівлі свиней.

Як видно з аналізу даних літератури, питання впливу концентрату сухого білкового соєвого кормового, отриманого за технологією експандування під тиском, на забійні та м'ясні якості свиней на відгодівлі залишається малодослідженим.

Мета і завдання досліджень. Метою досліджень було проаналізувати забійні та м'ясні якості відгодівельних свиней за використання в раціонах білкових соєвих інгредієнтів, виготовлених за різними технологіями (експандування під тиском, віджим під пресом, екструзія). Завданням дослідження є визначення можливості використання концентрату сухого білкового соєвого кормового в раціонах свиней на відгодівлі.

Методика проведення досліджень. В умовах державного підприємства «Експериментальна база «Надія»»» Інституту свинарства і агропромислового виробництва НААНУ в зимовий період 2011-2012 рр. було проведено науково-господарський дослід із вивчення впливу білкових кормів із сої на забійні та м'ясні якості свиней полтавської м'ясної породи. Для проведення досліджень після 15 -добового підготовчого періоду було відібрано 48 голів клінічно здорових свиней, які були сформовані в 4 групи аналогів за походженням, віком та живою масою. Утримувалися тварини в станках по дві голови. За основу була прийнята рецептура комбікорму, розроблена для свиней ТОВ «Вишгородський ЕКЗ» із використанням концентрату соєвого

* Науковий керівник - доктор сільськогосподарських наук, професор А. А. Полішук 


\section{СТОРІНКА МОЛОДОГО ВЧЕНОГО}

в кількості 18 \% та додавання кормів із ячменю, кукурудзи, пшениці та преміксу. Забій тварин проводили в умовах забійного цеху експериментальної бази. Досліди здійснюавали за загально прийнятими методиками у свинарстві. Термін залікового періоду становив 76 днів. Дослідження проведені за схемою досліду з використанням білкових кормів: група Д $1-$ концентрат сухий білковий соєвий кормовий, група Д 2 - макуха соєва, Д ${ }_{3}$ - екструдат соєвий, за контроль взята макуха соняшникова, група К (табл. 1).

Результати досліджень. Головним критерієм оцінки ефективності відгодівлі свиней $є$ рівень середньодобових приростів та затрати кормів на одиницю приросту живої маси (табл. 2).

За період досліду найкраще (порівнюючи 3 контрольними аналогами) росли тварини Д 1 та Д2 дослідних груп; їх прирости достовірно були вищими на 14,6 та 15,7 \% відповідно, при вищій конверсії корму по обмінній енергіï, сирому протеїну та комбікорму на 1 кг приросту. Найвища конверсія корму відмічена в першій дослідній групі Д1, відгодованій на концентраті соєвому. На 1 кг приросту живої маси у свиней даної групи було витрачено по 3,18 кг комбікорму, 37,68 МДж обмінної енергіï та 596,12 г сирого протеїну, що на 12,88; 1,15 й 4,7 \% відповідно нижче, ніж у контрольній групі.

\section{1. Схема науково-господарського досліду}

\begin{tabular}{|c|c|c|c|c|c|c|c|}
\hline \multirow[b]{2}{*}{ Група } & \multirow[b]{2}{*}{$\begin{array}{l}\text { По- } \\
\text { рода }\end{array}$} & \multirow{2}{*}{$\begin{array}{l}\text { Кіль- } \\
\text { кість } \\
\text { голів } \\
\end{array}$} & \multicolumn{2}{|c|}{ Стать } & \multicolumn{2}{|c|}{ Періоди досліду } & \multirow[b]{2}{*}{$\begin{array}{c}\text { Система } \\
\text { утримання }\end{array}$} \\
\hline & & & свинки & $\begin{array}{c}\text { кабан- } \\
\text { чики }\end{array}$ & $\begin{array}{c}\text { підготовчий } \\
\text { (15 днів) }\end{array}$ & $\begin{array}{l}\text { обліковий } \\
\text { (76 днів) }\end{array}$ & \\
\hline К - контрольна & $\Pi \mathrm{M}$ & 12 & 7 & 5 & $\begin{array}{c}\text { OP із макухою } \\
\text { соняшнику }\end{array}$ & $\begin{array}{c}\text { ОР } 82 \%+\text { макуха } \\
\text { соняшникова, } 18 \%\end{array}$ & $\begin{array}{l}\text { станкове, } \\
\text { по } 2 \text { гол. }\end{array}$ \\
\hline Д - дослідна & $\Pi \mathrm{M}$ & 12 & 7 & 5 & - & $\begin{array}{l}\text { OР } 82 \%+\text { концет- } \\
\text { рат соєвий, } 18 \%\end{array}$ & - \\
\hline$Д_{2}-$ дослідна & ПМ & 12 & 7 & 5 & - & $\begin{array}{c}\text { ОР } 82 \%+\text { макуха } \\
\text { соєва, } 18 \%\end{array}$ & - \\
\hline Д - дослідна & ПМ & 12 & 7 & 5 & - & $\begin{array}{l}\text { ОР } 82 \%+\text { екстру- } \\
\text { дат соєвий, } 18 \%\end{array}$ & - \\
\hline
\end{tabular}

2. Інтенсивність росту та затрат кормів у свиней $(n=12, \mathrm{M} \pm m)$

\begin{tabular}{|c|c|c|c|c|c|c|c|c|c|}
\hline \multirow{3}{*}{$\begin{array}{c}\text { Гру- } \\
\text { пи }\end{array}$} & \multirow{3}{*}{$\begin{array}{c}\text { Вік досягнен- } \\
\text { ня } 100 \text { кг, } \\
\text { днів } \\
\end{array}$} & \multirow{2}{*}{\multicolumn{2}{|c|}{ Середньодобовий приріст }} & \multicolumn{6}{|c|}{ Конверсія корму на 1 кг приросу } \\
\hline & & & & \multicolumn{2}{|c|}{ комбікорму } & \multicolumn{2}{|c|}{ обмінної енергії } & \multicolumn{2}{|c|}{ сирого протеїну } \\
\hline & & $\Gamma$ & $\%$ & Кг & $\%$ & МДж & $\%$ & $\Gamma$ & $\%$ \\
\hline $\mathrm{K}$ & & & & & & & 10 & & \\
\hline$Д_{1}$ & & & & & & & $\partial$ & & 95,30 \\
\hline$Д_{2}$ & & & & & 87 & & 89,34 & & 91,41 \\
\hline$Д_{3}$ & $232 \pm 3,32$ & $785 \pm 28,56$ & 109,00 & 3,33 & 91,23 & 39,79 & 93,82 & 607,16 & 97,07 \\
\hline
\end{tabular}

Примітка: *-P $\geq 0,95 ; * *-\mathrm{P} \geq 0,99 ; * * *-\mathrm{P} \geq 0,999$, до контрольної групи

3. Забійні та м'ясні якості свиней (n=3, M土m)

\begin{tabular}{|c|c|c|c|c|}
\hline \multirow{2}{*}{ Показник } & \multicolumn{4}{|c|}{ Група } \\
\cline { 2 - 5 } & $\mathrm{K}$ & $Д_{1}$ & $Д_{2}$ & $Д_{3}$ \\
\hline Жива маса перед забоєм, кг & $102,00 \pm 1,15$ & $103,00 \pm 1,00$ & $100,00 \pm 4,0$ & $104,00 \pm 3,00$ \\
\hline Маса парної туші, кг & $67,57 \pm 2,17$ & $69,76 \pm 0,36$ & $68,61 \pm 2,05$ & $70,38 \pm 2,8$ \\
\hline Забійний вихід туші, \% & $66,20 \pm 1,36$ & $67,73 \pm 0,32$ & $68,67 \pm 1,34$ & $67,63 \pm 0,88$ \\
\hline до контролю & - & 1,53 & 2,47 & 1,43 \\
\hline Площа «м'язового вічка», см ${ }^{2}$ & $33,27 \pm 3,57$ & $35,67 \pm 3,18$ & $36,63 \pm 3,35$ & $32,67 \pm 1,24$ \\
\hline у \% до контрольної групи & 100 & 107,2 & 110,1 & 98,2 \\
\hline Товщина шпику, мм: & & & & \\
\hline над 6-7-м грудними хребцями & $37,33 \pm 3,84$ & $35,33 \pm 2,60$ & $29,00 \pm 3,61$ & $32,67 \pm 4,26$ \\
\hline останнє ребро & $26,33 \pm 6,06$ & $25,67 \pm 3,84$ & $27,67 \pm 4,26$ & $25,00 \pm 5,00$ \\
\hline крижі & $32,33 \pm 5,46$ & $24,67 \pm 2,73$ & $29,00 \pm 6,03$ & $24,33 \pm 4,81$ \\
\hline у середньому & $32,00 \pm 4,86$ & $28,56 \pm 1,75$ & $28,56 \pm 4,57$ & $27,33 \pm 4,68$ \\
\hline у \% до контрольної групи & 100 & 121,08 & 91,21 & 87,14 \\
\hline
\end{tabular}


СТОРІНКА МОЛОДОГО ВЧЕНОГО

4. Морфологічний склад туші $(n=3, M \pm m)$

\begin{tabular}{|c|c|c|c|c|}
\hline \multirow{2}{*}{ Показник } & \multicolumn{4}{|c|}{ Група } \\
\hline & K & $Д_{1}$ & $Д_{2}$ & $Д_{3}$ \\
\hline Маса парної туші, кг & $67,57 \pm 2,17$ & $69,76 \pm 0,36$ & $68,61 \pm 2,05$ & $70,38 \pm 2,8$ \\
\hline Маса сала, кг & $23,92 \pm 1,08$ & $23,70 \pm 0,22$ & $22,53 \pm 1,95$ & $23,82 \pm 1,40$ \\
\hline у \% до контрольної групи & 100 & 99,08 & 94,19 & 99,58 \\
\hline Мaca м'яса, кг & $36,47 \pm 3,09$ & $39,02 \pm 0,68$ & $38,62 \pm 2,55$ & $38,80 \pm 2,14$ \\
\hline у \% до контрольної групи & 100 & 106,99 & 105,89 & 106,39 \\
\hline Маса кісток, кг & $7,18 \pm 0,14$ & $7,04 \pm 0,34$ & $7,46 \pm 0,67$ & $7,76 \pm 0,86$ \\
\hline у \% до контрольної групи & 100 & 98,05 & 103,90 & 108,08 \\
\hline Вихід, \% & & & & \\
\hline сала & $35,40 \pm 2,53$ & $33,97 \pm 0,45$ & $32,83 \pm 3,11$ & $33,85 \pm 2,10$ \\
\hline м'яса & $53,97 \pm 2,70$ & $55,93 \pm 0,54$ & $56,29 \pm 2,39$ & $55,13 \pm 1,15$ \\
\hline кісток & $10,63 \pm 0,38$ & $10,10 \pm 0,50$ & $10,88 \pm 0,72$ & $11,02 \pm 1,05$ \\
\hline $\begin{array}{c}\text { Відношення в туші } \\
\text { м'ясо / сало }\end{array}$ & $1: 0,53$ & $1: 0,65$ & $1: 0,72$ & $1: 0,63$ \\
\hline у \% до контрольної групи & 100 & 107,84 & 112,42 & 106,54 \\
\hline Маса окосту, кг & $11,16 \pm 0,38$ & $11,2 \pm 0,29$ & $12,03 \pm 0,57$ & $11,79 \pm 0,59$ \\
\hline у \% до контрольної групи & 100 & 100,36 & 107,80 & 105,65 \\
\hline $\begin{array}{c}\text { Енергетична цінність м'яса, } \\
\text { Ккал }\end{array}$ & $121,85 \pm 4,66$ & $127,56 \pm 14,11$ & $107,90 \pm 9,63$ & $109,42 \pm 8,91$ \\
\hline
\end{tabular}

Включення в раціон відгодівельного поголів'я свиней концентрату соєвого та інших соєвих кормів позитивно вплинуло на забійні та м'ясні якості піддослідних свиней (табл. 3).

Аналіз даних таблиці показав, що за показниками забійного виходу між молодняком дослідних груп суттєвої різниці не встановлено - він знаходився на рівні 67,63-68,67 \%, тварини цих груп переважали аналоги контрольної групи $(1,43-2,47$ \%). Площа «м'язового вічка» в середньому по дослідних групах становить $34,99 \mathrm{~cm}^{2}$ $\left(\min 32,67-\max 36,63 \mathrm{~cm}^{2}\right)$.

Відкладення сала по хребту проходить більш рівномірно у тварин, у раціонах яких використана макуха соєва; відповідно, в інших групах осаленість туш по хребту проходить менш рівномірно.

Простежується певна тенденція за забійними показниками у групах тварин, відгодованих на раціонах із включенням концентрату сухого білкового соєвого кормового та макухи соєвої, проте дані мають недостовірний характер.

Використання соєвих кормів у раціонах свиней на відгодівлі позитивно впливає на якість морфологічного складу туші (табл. 4).

\section{БІБЛІОГРАФІЯ}

1. Бабич А. О. Сучасне виробництво і використання сої. - К. : Урожай, 1993. - С. 298-300.

2. Перетятько Л. Г. Відгодівельні та м'ясні якості нових заводських ліній у полтавській м'ясній
Аналіз даних таблиці 4 свідчить, що процент виходу м'яса в тушах дослідних груп становить $55,13-56,29 \%$. Це доводить високий рівень м'ясності свиней, відгодованих на соєвих кормax.

Вихід сала в тушах становить 32,83-33,97 \% це дещо нижче від контрольної групи. Маса окосту, в середньому, становить 11,67 кг ( $\min 11,20$ - $\max 12,03$ кг), відношення м'яса до сала туші $1 / 0,63 \ldots 1 / 0,65$. За іншими показниками морфологічного складу різниця виявилася не суттєвою.

Висновок. Використання білкових кормів із сої, виготовлених за різними технологіями, зокрема концентрату сухого білкового соєвого кормового (експандування під тиском), макухи соєвої (віджим під пресом), ектрудату соєвого (екструзія) сприяє поліпшенню забійних та м'ясних якостей свиней: підвищенню виходу м'яса від 1,16 \% до 2,32 \%, при зниженні маси сала від 1,43\% до 2,57 \% по відношенню до контролю. Проведені дослідження показали можливість використання концентрату сухого білкового соєвого кормового в раціонах свиней на відгодівлі на рівні з іншими білковими кормами, які вивчалися в досліді.

породі свиней / Л. Г. Перетятько // Міжвід. темат. наук. зб. «Свинарство». - 2010. - Вип. 58. К. : Урожай - С. 38-39.

3. Петровська Н. І. Відгодівельні, забійні та 
м'ясні якості свиней великої білої породи за чистопородного розведення і схрещування / Н. І. Петровська, І.О.Головатюк, О.Ю.Ільницька // Збірник наукових праць ПДАТУ. - Кам'янецьПодільський. - 2012. - С. 202-204.

4. Полищук А. А., Семенов С. А. Прогнозирование аминокислотного состава соевых бобов по показателям качества их переработки / Вісник аграрної науки, - 1997. - № 8. - С. 17.

5. Семенов С. О. Соя в Україні і Росії: історичні аспекти та перспективи // Вісник Полтавської державної аграрної академії. - 2007. - Вип. 2. C. 51-55.

6. Сидоренко Р. П. Убойные и мясные качества свиней при введении в их рацион карнитина / Р. П. Сидоренко, В. А. Ситько, А. В. Корнеев //
Сборник научных трудов, посвященных 60летию зоотехнической науки Беларуси. - Т. 44. Вып. 2. - Жодино, 2009. - С. 212-219.

7. Трончук И. С., Полищук А. А. Экструдаты гороха и сои в рационах / Свиноводство, 1983. №2. - C. 10.

8. Чиков A. E. Соя и соевый шрот в рационах поpoсят. - Свиноводство. - 1979, №6. - С. 13-15.

9. Шаталин Б. Д. Соя в кормлении свиней. Респ. сб. «Корма и кормление с.-х. животных». К. : Урожай, 1975. - Вып. 36. - С. 64-68.

10. Ярмак К. М. Соя в раціонах племінного молодняка свиней // Міжвід. темат. наук. зб. «Свинарство». - 1993. - Вип. 49. - К. : Урожай. C. 72 . 